Invited review

\title{
Erythropoietin and cerebral vascular protection: role of nitric oxide
}

\author{
Anantha Vijay R SANTHANAM, Zvonimir S KATUSIC ${ }^{1}$ \\ Departments of Anesthesiology and Molecular Pharmacology and Experimental Therapeutics, Mayo Clinic College of Medicine, Rochester, \\ Minnesota 55905, USA
}

\section{Key words}

cerebral vasospasm; tissue protection; nitric oxide synthase; endothelium

\author{
${ }^{1}$ Correspondence to Dr Zvonimir S KATUSIC. \\ Phn 1-507-255-5156. \\ Fax 1-507-255-7300. \\ E-mail katusic.zvonimir@mayo.edu \\ Received 2006-06-23 \\ Accepted 2006-07-14 \\ doi: $10.1111 /$ j.1745-7254.2006.00441.x
}

\begin{abstract}
Cerebral vasospasm after subarachnoid hemorrhage ( $\mathrm{SAH}$ ) is a major clinical problem causing cerebral ischemia and infarction. The pathogenesis of vasospasm is related to a number of pathological processes including endothelial damage and alterations in vasomotor function leading to narrowing of arterial diameter and a subsequent decrease in cerebral blood flow. Discovery of the tissue protective effects of erythropoietin (EPO) stimulated the search for therapeutic application of EPO for the prevention and treatment of cerebrovascular disease. Recent studies have identified the role of EPO in vascular protection mediated by the preservation of endothelial cell integrity and stimulation of angiogenesis. In this review, we discuss the EPO-induced activation of endothelial nitric oxide (NO) synthase and its contribution to the prevention of cerebral vasospasm.
\end{abstract}

\section{Introduction}

Erythropoietin (EPO), produced in the fetal liver and adult kidney, is a 165 amino acid $(\sim 30 \mathrm{kDa})$ serum glycoprotein, responsible for the proliferation, survival and differentiation of erythroid progenitor cells. The production and secretion of EPO is oxygen-dependent. Once a hypoxic stimulus is received, EPO is released into the peripheral circulation, and upon arrival in the bone marrow, EPO binds to its receptor on the erythroid progenitor cells and leads to erythropoiesis ${ }^{[1]}$. In addition, EPO stimulates the proliferation and maturation of erythroid cells ${ }^{[2,3]}$.

\section{Tissue protective effects of EPO}

The concept that erythropoiesis was the only original principal action of EPO changed with the realization that EPO and its receptor (EPOR) were expressed in the brain, heart, and uterus ${ }^{[1,4,5]}$. In addition to its effect on erythroid progenitor cells, EPO exerts several biological effects on endothelial, vascular smooth muscle, myocardial, mesangial and neuronal cells ${ }^{[6-12]}$.

The production and secretion of EPO and the expression of EPOR are controlled by tissue oxygen supply and are mainly regulated by hypoxia-inducible factors ${ }^{[13]}$. In addition to hypoxia, EPO can be upregulated by estrogen, insulin, pro-inflammatory cytokines, such as tumor necrosis factor- $\alpha$ $(\mathrm{TNF}-\alpha)$ and interleukin-1 $\beta$ (IL-1 $\beta$ ), as well as byEPO itself ${ }^{[14-18]}$.

The mechanisms of tissue protection by EPO include several different signal transduction pathways. When EPO binds to EPOR, it causes dimerization of the receptor, autophosphorylation of Janus-tyrosine-kinase-2 (JAK-2) and receptor activation. JAK-2 activation leads to several downstream signaling pathways including Ras-mitogen activated protein kinase (MAPK), phosphatidylinositol-3-kinase/protein kinase B (PI3K/Akt) and the transcription factor signal transducers and activators of transcription-5 (STAT-5; Figure 1). Additionally, EPO has been shown to modulate intracellular calcium concentrations in excitable cells by activating phospholipase $\mathrm{C}-\gamma$. Another mechanism that may contribute to the protective role of EPO is the enhancement of antioxidant defense mechanisms. EPO increases the activity of antioxidant enzymes, such as superoxide dismutase, glutathione peroxidase and catalase, and protects the brain against ischemic damage ${ }^{[1,20]}$. EPO also seems to modulate the proliferation and differentiation of stem cells and can increase the viability of embryonic cortical neurons, promote cell survival and upregulate the proliferative response of neuronal progenitor cells ${ }^{[21,22]}$. In addition, EPO increases the number of endothelial progenitor cells mobilized from the bone marrow ${ }^{[23,24]}$. The broad efficacy of EPO observed 


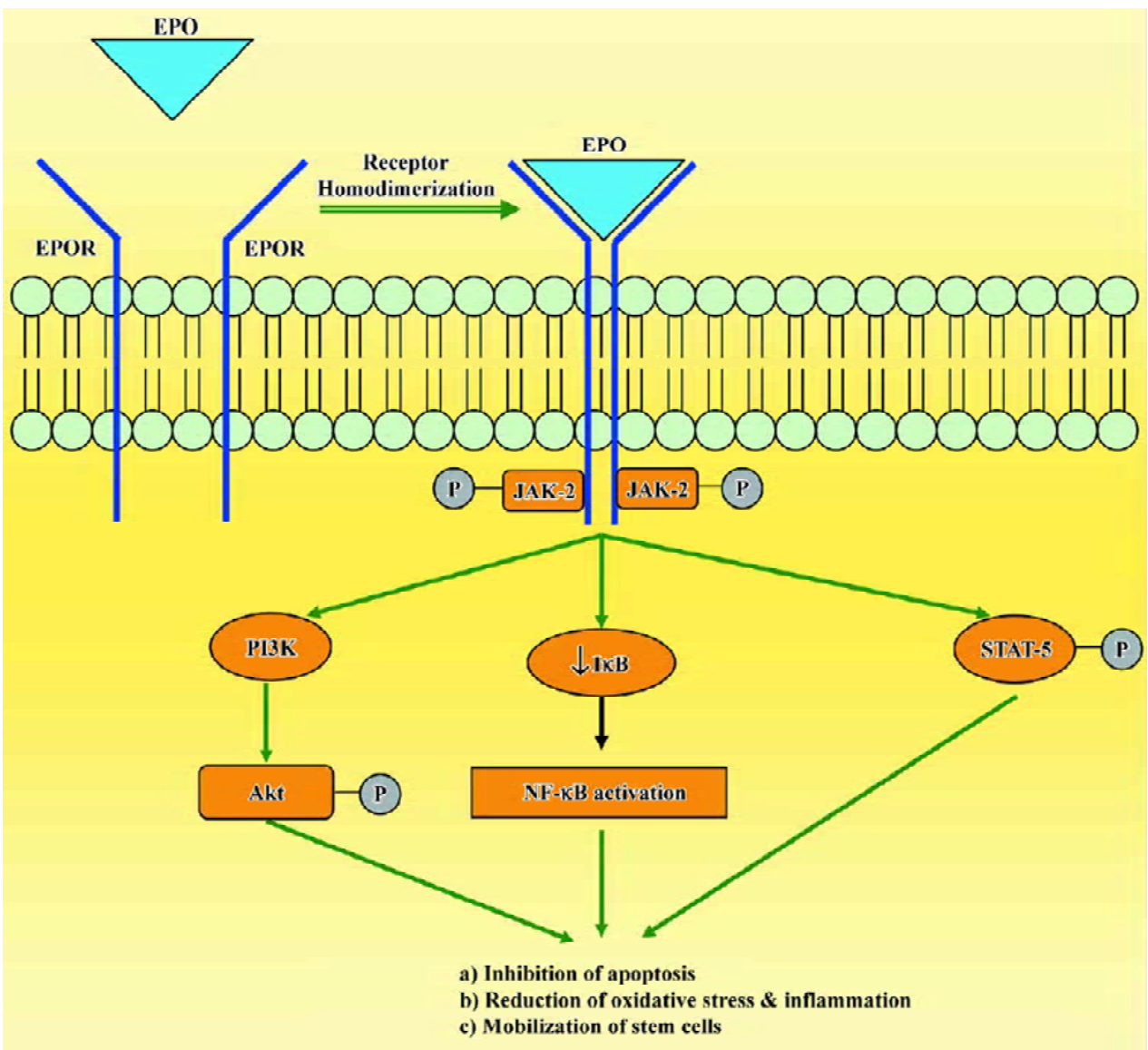

Figure 1. Schematic illustration of the mechanisms of tissue protection by erythropoietin. The binding of EPO to its receptor (EPOR) produces a conformational change and activation, leading to phosphorylation of JAK-2. Phosphorylation of JAK-2 leads to the activation of phosphatidyl inositol-3-kinase (PI3K), STAT-5 and inhibitor of transcription factor NF- $\kappa B$ (I $\kappa B)$. NF- $\kappa B$ dissociates

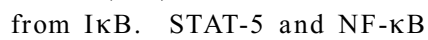
translocate to the nucleus and promote expression of tissue protective genes leading to the inhibition of apoptosis, reduction of oxidative stress and inflammation. in experimental models of disease depends on its ability to inhibit apoptosis, restoration of vascular autoregulation, attenuation of inflammatory responses and augmentation of restorative functions, including the direct recruitment of stem cells $^{[25,26]}$.

Of all the non-hematopoietic biological roles of EPO, the contribution of EPO to neuroprotection has received the most attention. The ability of EPO to penetrate the blood-brain barrier has been pivotal to its application as a neurotherapeutic agent, as intrathecal administration is not practical in most clinical settings ${ }^{[27,28]}$. A recent proof-of-concept clinical trial demonstrated beneficial effect of EPO in patients who suffered an acute stroke, and encouraged the evaluation of this cytokine in various models of tissue injury ${ }^{[29]}$.

\section{Role of nitric oxide (NO) in the cerebral vascular protective effects of EPO}

EPO plays a dual role in vascular protection by preserving endothelial cell integrity and by promoting angiogenesis ${ }^{[30-32]}$. In transgenic mice overexpressing human EPO, endothelial NO synthase (eNOS) expression in the arteries increased and was accompanied by enhanced NO-mediated endothe- lium-dependent relaxation and elevated circulating and vascular tissue $\mathrm{NO}^{[33]}$. The ability of EPO to increase NOS activity in endothelial cells ${ }^{[14,34]}$ prompted us to investigate the contribution of endothelium-derived NO to the vascular protective effects of EPO.

To study the cerebrovascular effects of EPO, an adenovirus encoding recombinant EPO (AdEPO) was injected intracisternally into rabbits. Forty-eight hours later, the expression of EPO was observed in the basilar arteries. In arteries transduced with AdEPO, the expressions of eNOS and its phosphorylated (S1177) form were increased. Basal levels of cyclic GMP were significantly elevated in the arteries transduced with AdEPO, consistent with increased NO production (Figure 2) ${ }^{[35]}$. Although, adenovirus-mediated gene transfer into the cisterna magna was performed to increase EPO expression locally in the cerebral arteries, we were able to achieve concentrations of EPO in plasma known to be clinically therapeutic (about $2-5 \mathrm{U} / \mathrm{mL}$ ), possibly by the crossing of EPO from the cerebrospinal fluid into the circulating blood $^{[27]}$. In this regard, we wish to point out that the vascular benefits obtained with EPO are most likely dependent on its concentration in the plasma. Although sys- 




Figure 2. Representative Western blots demonstrating increased expressions of (A) EPO and EPOR and (B) eNOS and phosphoS1177-eNOS in the cerebral arteries of rabbits transduced with AdEPO. Reproduced with permission from Santhanam et al. (Ref 35).

temic administration of EPO ( $>$ about 5 times the hematopoietic dose) has been shown to exert tissue protective effects, very high circulating concentrations of EPO (in the range of 20-200 U/mL) exerts vasoconstriction, in part by reducing eNOS expression and/or increasing cytosolic calcium content of vascular smooth muscle cells by the stimulation of protein kinase $\mathrm{C}$ and phospholipase $\mathrm{C} \gamma 1^{[10,36-39]}$. Although the effects obtained with AdEPO were similar to those obtained on transgenic mice overexpressing human $\mathrm{EPO}^{[33]}$, the red blood cells (RBC) number in the arteries transduced with AdEPO were not increased, arguing against the contribution of shear stress in increased NO production.

Cerebral vasospasm after subarachnoid hemorrhage (SAH) leads to high morbidity and mortality of patients affected by ruptured cerebral aneurysms. Demonstrated neuroprotective effects of $\mathrm{EPO}^{[40-42]}$ have been associated with a reduction in vasoconstriction observed in EPO-treated rabbits subjected to SAH. Overexpression of EPO in cerebral arteries reversed vasospasms induced by the injection of autologous blood into the cisterna magna. Arteries transduced with recombinant EPO demonstrated significant augmentation of the endothelium-dependent relaxations to acetylcholine. Transduction with AdEPO further increased the expression of phosphorylated Akt and eNOS andelevated basal levels of cGMP in the spastic arteries (Figure 3$)^{[43]}$. The neuroprotective effects of EPO obtained in animal models of ischemic brain injury and SAH could be explained in part by the augmented basal production of NO in the endothelium. Furthermore, it is possible that the administration of recombinant EPO reduced the infiltration of mono-
A

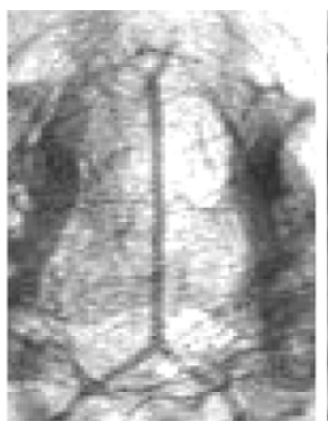

SAH+AdLacZ

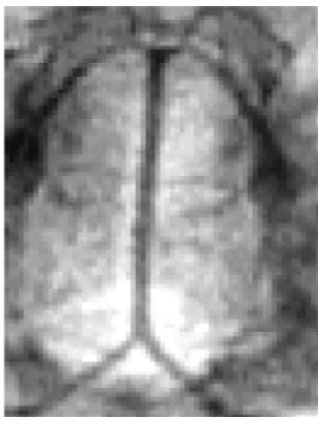

SAH+AdEpo
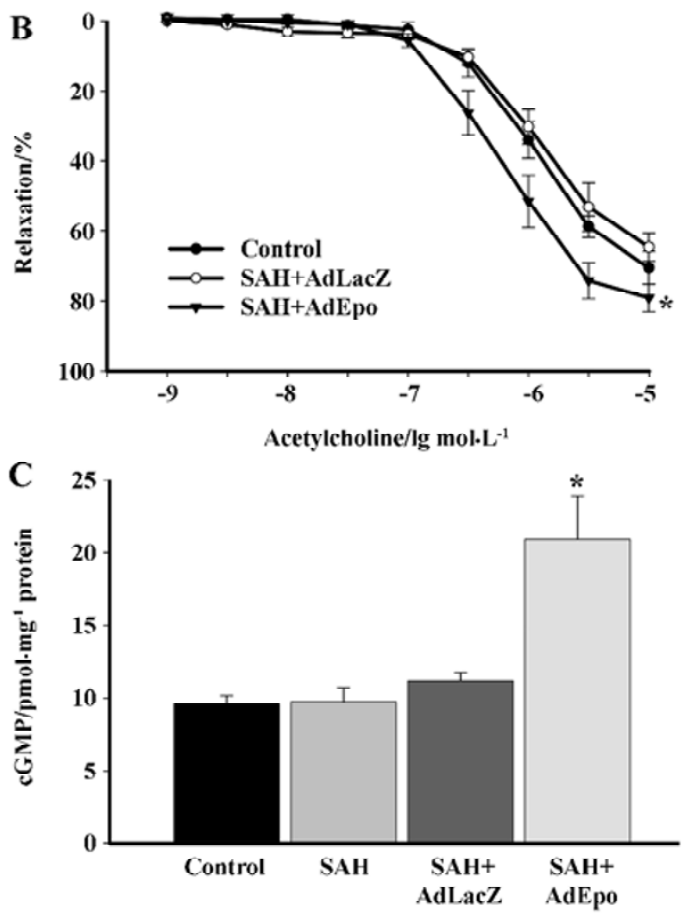

Figure 3. (A) Representative angiograms of the basilar arteries of rabbits subjected to $\mathrm{SAH}$ followed by intracisternal injection with AdLacZ or AdEpo; (B) Endothelium-dependent relaxations to acetylcholine in the basilar arteries of control rabbits and rabbits subjected to SAH followed by gene transfer with AdLacZ or AdEpo. Relaxations were obtained during contractions induced by histamine $\left(3 \times 10^{-7} \mathrm{~mol} / \mathrm{L}\right.$ to $\left.1 \times 10^{-6} \mathrm{~mol} / \mathrm{L}\right)$. Data are expressed as percentage of maximal relaxation induced by $3 \times 10^{-4} \mathrm{~mol} / \mathrm{L}$ papaverine; $100 \%=$ $1.34 \pm 0.19 \mathrm{~g}, 1.10 \pm 0.07 \mathrm{~g}, 0.96 \pm 0.10 \mathrm{~g}$ in the control, SAH+AdLacZ and $\mathrm{SAH}+\mathrm{AdEpo}$ arteries respectively $(n=5)$. "Significantly different in $\mathrm{SAH}+\mathrm{AdEpo}$ comparison to $\mathrm{SAH}+\mathrm{AdLacZ}(P<0.05)$; (C) Bar diagram representing the levels of basal cyclic guanosine 5'-monophosphate (cGMP) among the basilar arteries of control or rabbits subjected to SAH or SAH rabbits transduced with AdLacZ or AdEpo. ${ }^{*}$ Differences in the levels of cGMP among control or SAH and $\mathrm{SAH}+\mathrm{AdEpo}$ are statistically significant $(P<0.05, n=5)$. Reproduced with permission from Santhanam et al. (Ref 43).

nuclear inflammatory cells after $\mathrm{SAH}^{[44,45]}$. 
In cerebral circulation, EPO has a direct action on the endothelium and increases NO bioavailability by the upregulation of eNOS (Figure 4). Understanding of the multiple tissue protective effects of EPO provides impetus for translation of these findings into the clinical arena. However, the hematopoietic side effects of recombinant EPO, in particular with repeated high doses, have to be avoided to achieve selective tissue protective effects. In such circumstances, the non-hematopoietic analogues of $\mathrm{EPO}^{[46,47]}$ offer a promise of utilizing only the tissue protective benefits of this potent hematopoietic cytokine.

\section{References}

1 Li F, Chong ZZ, Maiese K. Erythropoietin on a tightrope: balancing neuronal and vascular protection between intrinsic and extrinsic pathways. Neurosignals 2004; 13: 265-89.

2 Broudy VC, Lin N, Brice M, Nakamoto B, Papayannopoulou T. Erythropoietin receptor characteristics on primary human erythroid cells. Blood 1991; 77: 2583-90.

3 Fisher JW. Erythropoietin: physiology and pharmacology update.
Exp Biol Med 2003; 228: 1-14.

4 Maiese K, Li F, Chong ZZ. New avenues for exploration of erythropoietin. JAMA 2005; 295: 90-5.

5 Brines M, Cerami A. Emerging biological roles for erythropoietin in the nervous system. Nat Rev Neurosci 2005; 6: 484-94.

6 Anagnostou A, Liu Z, Steiner M, Chin K, Lee ES, Kesseimian N, et al. Erythropoietin receptor mRNA expression in human endothelial cells. Proc Natl Acad Sci USA 1994; 91: 3974-8.

7 Gogusev J, Zhu DL, Herembert T, Ammarguellat F, Marche P, Drueke T. Effect of erythropoietin on DNA synthesis, protooncogene expression and phospholipase $\mathrm{C}$ activity in rat vascular smooth muscle cells. Biochem Biophys Res Commun 1994; 199: 977-83.

8 Ammarguellat F, Gogusev J, Drueke TB. Direct effect of erythropoietin on vascular smooth muscle cell via a putative erythropoietin receptor. Nephrol Dial Transplant 1996; 11: 687-92.

9 Wald MR, Borda ES, Sterin-Borda L. Mitogenic effect of erythropoietin on neonatal rat cardiomyocytes: Signal transduction pathways. J Cell Physiol 1996; 167: 461-6.

10 Morakkabati N, Gollnick F, Meyer R, Fandrey J, Jelkmann W. Erythropoietin induces $\mathrm{Ca}^{2+}$ mobilization and contraction in rat mesangial and aortic smooth muscle cultures. Exp Hematol 1996; 24: $392-7$.



Figure 4. Schematic representation of cerebral vascular protection by EPO. Binding of EPO to its receptor (EPOR) on the endothelial cells leads to phosphorylation of JAK-2. Phosphorylation of JAK-2 leads to activation of PI3K/Akt pathway and phosphorylation of endothelial NO synthase and increased NO production resulting in cerebral vasodilatation. 
11 Marrero MB, Venema RC, Ma H, Ling B, Eaton DC. Erythropoietin receptor-operated $\mathrm{Ca}^{2+}$ channels: activation by phospholipase C- $\gamma 1$. Kidney Int 1998; 3: 1259-68.

12 Assandri R, Egger M, Gassmann M, Niggli E, Bauer C, Forster I, et al. Erythropoietin modulates intracellular calcium in human neuroblastoma cell line. J Physiol 1999; 516: 343-52.

13 Jelkmann W. Molecular biology of erythropoietin. Intern Med 2004; 43: 649-59.

14 Beleslin-Cokic BB, Cokic VP, Yu X, Weksler BB, Schechter AN, Noguchi CT. Erythropoietin and hypoxia stimulate erythropoietin receptor and nitric oxide production by endothelial cells. Blood 2004; 104: 2073-80.

15 Chandel NS, McClintock DS, Feliciano CE, Wood TM, Melendez JA, Rodriguez AM, et al. Reactive oxygen species generated at mitochondrial complex III stabilize hypoxia-inducible factor1 alpha during hypoxia: a mechanism of $\mathrm{O}_{2}$ sensing. J Biol Chem 2000; 275: 25130-8.

16 Chikuma M, Masuda S, Kobayashi T, Nagao M, Sasaki R. Tissuespecific regulation of erythropoietin production in the murine kidney, brain, and uterus. Am J Physiol Endocrinol Metab 2000; 279: E1242-8.

17 Chin K, Yu X, Beleslin-Cokic B, Liu C, Shen K, Mohrenweiser $\mathrm{HW}$, et al. Production and processing of erythropoietin receptor transcripts in brain. Brain Res Mol Brain Res 2000; 81: 2942.

18 Nagai A, Nakagawa E, Choi HB, Hatori K, Kobayashi S, Kim SU. Erythropoietin and erythropoietin receptors in human CNS neurons, astrocytes, microglia, and oligodendrocytes grown in culture. J Neuropathol Exp Neurol 2001; 60: 386-92.

19 Sakanaka M, Wen TC, Matsuda S, Masuda S, Morishita E, Nagao $\mathrm{M}$, et al. In vivo evidence that erythropoietin protects neurons from ischemic damage. Proc Natl Acad Sci USA 1998; 95: 463540 .

20 Genc S, Akhisaroglu M, Kuralay F, Genc K. Erythropoietin restores glutathione peroxidase activity in 1-methyl-4-phenyl-1, 2,3,6-tetrahydropyridine-induced neurotoxicity in C57BL mice and stimulates murine astroglial glutathione peroxidase production in vitro. Neurosci Lett 2002; 321: 73-6.

21 Studer L, Csete M, Lee SH, Kabbani N, Walikonis J, Wold B, et al. Enhanced proliferation, survival, and dopaminergic differentiation of CNS precursors in lowered oxygen. J Neurosci 2000; 20: 7377-83.

22 Shingo T, Sorokan ST, Shimazaki T, Weiss S. Erythropoietin regulates the in vitro and in vivo production of neuronal progenitors by mammalian forebrain neural stem cells. J Neurosci 2001; 21: 9733-43.

23 Heeschen C, Aicher A, Lehmann R, Fichtlscherer S, Vasa M, Urbich $\mathrm{C}$, et al. Erythropoietin is a potent physiologic stimulus for endothelial progenitor cell mobilization. Blood 2003; 102 : 1340-6.

24 Bahlmann FH, de Groot K, Spandau JM, Landry AL, Hertel B, Duckert $\mathrm{T}$, et al. Erythropoietin regulates endothelial progenitor cells. Blood 2004; 103: 921-6.

25 Grasso G, Sfacteria A, Cerami A, Brines M. Erythropoietin as a tissue-protective cytokine in brain injury: what do we know and where do we go? Neuroscientist 2004; 10: 93-8.

26 Lipton SA. Erythropoietin for neurologic protection and diabetic neuropathy. N Engl J Med 2004; 350: 2516-7.
27 Brines ML, Ghezzi P, Keenan S, Agnello D, de Laner-Olle NC, Cerami C, et al. Erythropoietin crosses the blood-brain barrier to protect against experimental brain injury. Proc Natl Acad Sci USA 2000; 97: 10 526-31.

28 Juul S. Erythropoietin in the brain, and its use to prevent hypoxic-ischemic brain damage. Acta Paediatr 2002; 438: 36-42.

29 Ehrenreich H, Hasselblatt M, Dembowski C, Cepek L, Lewczuk $\mathrm{P}$, Stiefel M, et al. Erythropoietin therapy for acute stroke is both safe and beneficial. Mol Med 2002; 8: 495-505.

30 Chong ZZ, Kang JQ, Maiese K. Angiogenesis and plasticity: role of erythropoietin in vascular systems. J Hematother Stem Cell Res 2002; 11: 863-71.

31 Chong ZZ, Kang JQ, Maiese K. Apaf-1, Bcl- $\mathrm{x}_{\mathrm{L}}$, cytochrome c, and caspase-9 form the critical elements for cerebral vascular protection by erythropoietin. J Cereb Blood Flow Metab 2003; 23: 320-30.

32 Chong ZZ, Kang JQ, Maiese K. Erythropoietin is a novel vascular protectant through activation of Akt 1 and mitochondrial modulation of cysteine proteases. Circulation 2002; 106: 2973-9.

33 Ruschitzka FT, Wenger RH, Stallmach T, Quaschning T, de Wit $\mathrm{C}$, Wagner $\mathrm{K}$, et al. Nitric oxide prevents cardiovascular disease and determines survival in polyglobulic mice overexpressing erythropoietin. Proc Natl Acad Sci USA 2000; 97: 11 609-13.

34 Banerjee D, Rodriguez M, Nag M, Adamson JW. Exposure of endothelial cells to recombinant human erythropoietin induces nitric oxide synthase activity. Kidney Int 2000; 57: 1895-904.

35 Santhanam AV, Smith LA, Nath KA, Katusic ZS. In vivo stimulatory effect of erythropoietin on endothelial nitric oxide synthase in cerebral arteries. Am J Physiol Heart Circ Physiol 2006; 291: H781-6.

36 Heidenreich S, Rahn KH, Zidek W. Direct vasopressor effect of recombinant human erythropoietin on renal resistance vessels. Kidney Int 1991; 39: 259-65.

37 Vaziri ND, Zhou XJ, Naqvi F, Smith J, Oveisi F, Wang ZQ, et al. Role of nitric oxide resistance in erythropoietin-induced hypertension in rats with chronic renal failure. Am J Physiol 1996; 271: E1 13-22.

38 Wang XQ, Vaziri ND. Erythropoietin depresses nitric oxide synthase expression by human endothelial cells. Hypertension 1999; 33: 894-9.

39 Akimoto T, Kusano E, Muto S, Fujita N, Okada K, Saito T, et al. The effect of erythropoietin on interleukin-1 $\beta$ mediated increase in nitric oxide synthesis in vascular smooth muscle cells. J Hypertens 1999; 17: 1249-56.

40 Alafaci C, Salpietro F, Grasso G, Sfacteria A, Passalacqua M, Morabito A, et al. Effect of recombinant human erythropoietin on cerebral ischemia following experimental subarachnoid hemorrhage. Eur J Pharmacol 2000; 406: 219-25.

41 Buemi M, Grasso G, Corica F, Calapai G, Salpietro FM, Casuscelli $\mathrm{T}$, et al. In vivo evidence that erythropoietin has a neuroprotective effect during subarachnoid hemorrhage. Eur J Pharmacol 2000; 392: 31-4.

42 Grasso G, Buemi M, Alafaci C, Sfectaria A, Passalacqua M, Sturiale A, et al. Beneficial effects of systemic administration of recombinant human erythropoietin in rabbits subjected to subarachnoid hemorrhage. Proc Natl Acad Sci USA 2002; 99: 5627-31.

43 Santhanam AV, Smith LA, Akiyama M, Rosales AG, Bailey KR, Katusic ZS. Role of endothelial NO synthase phosphorylation in 
cerebrovascular protective effect of recombinant erythropoietin in subarachnoid hemorrhage-induced cerebral vasospasm. Stroke 2005; 36: 2731-7.

44 Villa P, Bigini P, Mennini T, Agnello D, Laragione T, Cagnotto A, et al. Erythropoietin selectively attenuates cytokine production and inflammation in cerebral ischemia by targeting neuronal apoptosis. J Exp Med 2003; 198: 971-5.

45 Lee ST, Chu K, Sinn DI, Jung KH, Kim EH, Kim SJ, et al. Erythropoietin reduces perihematomal inflammation and cell death with eNOS and STAT3 activations in experimental intracerebral hemorrhage. J Neurochem 2006; 96: 1728-39.

46 Leist M, Ghezzi P, Grasso G, Bianchi R, Villa P, Fratelli M, et al. Derivatives of erythropoietin that are tissue protective but not erythropoietic. Science 2004; 305: 239-42.

47 Coleman TR, Westenfelder C, Togel FE, Yang Y, Hu Z, Swenson $\mathrm{L}$, et al. Cytoprotective doses of erythropoietin or carbamylated erythropoietin have markedly different procoagulant and vasoactive activities. Proc Natl Acad Sci USA 2006; 103: 5965-70.

\title{
The $10^{\text {th }}$ Tamagawa-Riken Dynamic Brain Forum (DBF'07)
}

\author{
March 5-9, 2007
}

Nagano Prefecture, Japan

Registration and further information please send e-mail to

Secretary: S. Nagayama

Email:nagayama@lab.tamagawa.ac.jp

Address: Department of Intelligent Information Systems, Faculty of Engineering, Tamagawa University, 6-1-1 Tamagawagakuen, Machida, Tokyo, 194-8160, Japan Website: http:/www.tamagawa.ac.jp/sisetu/gakujutu/brain/dbf2007/index.html 